\title{
Antibacterial Activity of Diphenyltin(IV) and Triphenyltin(IV) 3-Chlorobenzoate Againts Pseudomonas aeruginosa and Bacillus subtilis
}

\author{
ANNISSA ${ }^{1,2}$, TATI SUHARTATI, YANDRI ${ }^{1}$ and SUTOPO HADI ${ }^{1, *}$ \\ 'Department of Chemistry, Faculty of Mathematics and Natural Sciences, Universitas Lampung, \\ Bandar Lampung, 35145, Indonesia. \\ ${ }^{2}$ Sekolah Tinggi IImu Kesehatan Faletehan, Serang-Banten,4216, Indonesia. \\ ${ }^{*}$ Corresponding author E-mail : sutopo.hadi@ fmipa.unila.ac.id \\ http://dx.doi.org/10.13005/ojc/330310
}

(Received: May 09, 2017; Accepted: May 31, 2017)

\begin{abstract}
In this paper, we reported the syntheses and antibacterial activity test of 2 organotin(IV) compounds, diphenyltin (IV) di-3-chlorobenzoate (2) and triphenyltin (IV) 3-chlorobenzoate (4). These two compounds were prepared by the reaction of diphenyltin (IV) dihydroxide and triphenyltin (IV) hydroxide with 3-chlorobenzoic acid. These compounds were characterized by ${ }^{1} \mathrm{H}$ and ${ }^{13} \mathrm{C} \mathrm{NMR}$, IR, UV-Vis spectroscopies and also based on the microanalytical data. The results of antibacterial activity by diffusion method against Pseudomonas aeruginosa and Bacillus subtilis showed that the triphenyltin(IV) 3-chlorobenzoate was active at concentration of $3.956 \times 10^{-4} \mathrm{M}(200 \mathrm{ppm})$, while the chloramphenicol gave inhibition of $6.1894 \times 10^{-4} \mathrm{M}(200 \mathrm{ppm})$, although the halozone was bigger. This result indicated that compound $\mathbf{4}$ is potentially to be used as antibacterial substance, although the search of other derivative of organotin (IV) with other ligands is still needed to get much higher and much better activity.
\end{abstract}

Keywords: antibacteria, B. subtilis, organotin(IV) 3-chlorobenzoate, P. aeruginosa

\section{INTRODUCTION}

Infectious disease is one of the main problems in the world health, as almost every country faces this problem ${ }^{1}$. The main cause of infectious diseases is due to bacteria, of them are negative gram bacteria $P$. aeruginosa and positive gram bacteria $B$. subtilis'. P. aeruginosa causes many diseases such as infections of wounds, burns, bluish green pus, urinary channel, respiratory causing the pneumonia with necrosis, light external otitis on swimmers and eyes. B. subtilis can cause damage on canned food which can cause gastroenteritis to the consumers ${ }^{2}$.

One of the ways that can be carried out to inhibit the growth of bacteria in every organism is by applying antibacterial substances ${ }^{3}$. Based on the use of antibacterial substances, they can be categorized as disinfectant, antiseptic, sterilizer, 
sanitizer ${ }^{4}$. The inhibition of bacterial growth by antibacterial substances can be done by cell disruption mechanism which is by inhibiting its formation or changing it after being formed, alteration of cytoplasm membran permeability that cause the nutrient is out from inside the cell, inhibition of enzyme activity and preventing the synthesis of nucleid acid and protein ${ }^{1}$.

Organotin (IV) compounds are well known to have wide applications and one of the organometallic compounds widely applied and used due to their significants in many biological activities ${ }^{5-21}$. These compounds and their derivatives have been known as antifungal ${ }^{9-11}$, anticancer and antitumour ${ }^{12-15}$, antiviral $^{16}$, antibacterial ${ }^{17-18}$ and anticorrosion ${ }^{20-24}$. The biological activity of these compounds because of the number and basic character of organic ligand attached to metal center $\mathrm{Sn}^{19}$. The anions bound to Sn metal are the secondary factor in determining the organotin (IV) compounds.

In this paper, we report the antibacterial activity of organotin (IV) derivatives of diphenyltin (IV) and triphenyltin (IV) with 3-chlorobenzoic acid againts negative gram bacteria $P$. aeruginosa and positive gram bacteria $B$. subtilis

\section{EXPERIMENTAL}

All reagents used were $A R$ grade. Diphenyltin(IV) dichloride $\left(\left[\left(\mathrm{C}_{6} \mathrm{H}_{5}\right)_{2} \mathrm{SnCl}_{2}\right]\right)$, triphenyltin(IV) chloride $\left(\left[\left(\mathrm{C}_{6} \mathrm{H}_{5}\right)_{3} \mathrm{SnCl}\right]\right)$, 3-chlorobenzoic acid were obtained from Sigma, sodium hydroxide $(\mathrm{NaOH})$ and methanol $\left(\mathrm{CH}_{3} \mathrm{OH}\right)$ were JT Baker products, and the control drug, chloramphenicol were used as received without further purification. Negative gram bacteria $P$. aeruginosa was obtained from Department of Microbiology, University of Indonesia, Jakarta and positive gram bacteria $B$. subtilis was obtained from Biochemistry Laboratory, Department of Chemistry, University of Lampung Indonesia.

The UV spectra were obtained using a UV-Shimadzu UV-245 Spectrophotometer. The measurements were conducted in the UV region and were measured in $1 \mathrm{~mL}$ quartz-cells. The solvent used to dissolve sample was methanol. The concentration used in the measurements were 1.0x10-4 M. A Bruker AV $600 \mathrm{MHz}$ NMR (600 MHz for ${ }^{1} \mathrm{H}$ and $150 \mathrm{MHz}$ for ${ }^{13} \mathrm{C}$ ) were used to obtain ${ }^{1} \mathrm{H}$ and ${ }^{13} \mathrm{C}$ NMR spectra. All experiments were run in DMSO- $D_{6}$ at $298 \mathrm{~K}$. The number of scans used for ${ }^{1} \mathrm{H}$ experiments were 32 with reference at DMSO signal at $2.5 \mathrm{ppm}$, while the ${ }^{13} \mathrm{C}$ were $1000-4000$ scans with the reference of DMSO signal at $39.5 \mathrm{ppm}$. A Bruker VERTEX 70 FT-IR spectrophotometer were used to record the IR Spectra, $\mathrm{KBr}$ discs were used in all measurements. The range of $4000-400 \mathrm{~cm}^{-1}$ was applied. Elemental analyses (CHNS) were performed on Fision EA 1108 series elemental analyser.

\section{Preparation of organotin (IV) chlorobenzoate}

The organotin(IV) chlorobenzoate compounds used in this work were prepared based on the procedure previously reported ${ }^{9,14,15,20,21}$. These procedure was obtained from adaption from the work by Szorcsik et al. ${ }^{24}$. For example the procedure in the preparation of dibutyltin(IV) dihydroxybenzoate was as follows:

To $3.44 \mathrm{~g}(0.01 \mathrm{~mol})\left[\left(\mathrm{C}_{6} \mathrm{H}_{5}\right)_{2} \mathrm{SnCl}_{2}\right]$ in 50 $\mathrm{mL}$ methanol was added $0.8 \mathrm{~g}(0.02 \mathrm{~mol}) \mathrm{NaOH}$. The reaction mixtures were stirred for about 45 minutes. Compound 2 was precipitated out as white solid, filtered off and dried in vacuo till they are ready for analysis and further reaction. The average yield was $2.33 \mathrm{~g}(94 \%)$.

To $0.4605 \mathrm{~g}$ (1.5 mmol) compound 2 in 50 $\mathrm{mL}$ of methanol was added with 2 mole equivalents of 3-chlorobenzoic acid $(0.313 \mathrm{~g})$ and was refluxed for 4 hours at $60-61^{\circ} \mathrm{C}$. After removal of the solvent by rotary evaporator, the produced compounds $\left[\left(\mathrm{C}_{6} \mathrm{H}_{5}\right)_{2} \mathrm{Sn}\left(\mathrm{OOCC}_{6} \mathrm{H}_{4} \mathrm{Cl}\right)_{2}\right]$ were dried in vacuo until they are ready for analysis and further use for antibacterial activity test. The average yields were more than $90 \%$.

A similar procedure was also adapted in the preparation of triphenyltin (IV) derivatives, $\left[\left(\mathrm{C}_{6} \mathrm{H}_{5}\right)_{3} \mathrm{~S}\right.$ $\mathrm{n}\left(\mathrm{OOCC}_{6} \mathrm{H}_{4} \mathrm{Cl}\right)$ ], where only one mole equivalent of the 3- chlorobenzoic acid was used.

\section{Antibacterial Activity Test Preparation of Media}

The media used for the activity test was nutrient agar (NA). $2.8 \mathrm{~g}$ of NA was dissolved in 100 $\mathrm{mL}$ aquadest, heated and sterilized by autoclave at 
$121^{\circ} \mathrm{C}$, pressure of $1 \mathrm{~atm}$ for 15 minutes. $15 \mathrm{~mL}$ of steril media was placed on sterilized petri disc. It was carried out in laminar air flow, and left the media to solidify.

\section{Antibacterial activity test by diffusion test}

One ose of $P$. aeruginosa and $B$. subtilis was diluted with $2 \mathrm{~mL}$ of salin solution ( $\mathrm{NaCl} 0.85 \%$ ) and was used as bacteria suspension. $1 \mathrm{~mL}$ of the suspension was then innoculated on NA, flattened with spreader. 4 paper discs were prepared. The first paper disc contained the positive control (chloramphenicol), the second was negative control containing the solvent used for the test, i.e. DMSO, the third and fourth paper discs containing the organotin (IV) compounds tested. All paper discs were then placed on the surface of media. They were then incubated for 1 day at $37^{\circ} \mathrm{C}$ and were monitored to see the inhibition zone. The compounds found as the most active, i.e. giving the most effective inhibition was then tested with the dilution method.

\section{Antibacterial activity test dilution Test}

Based on the result of diffusion test, the most effective concentration inhibition zones were obtained for both diphenyltin (IV) di-3-chlorobenzoate and triphenyltin (IV) chlorobenzoate. These compounds with the most active concentration were then dissolved with aquadest- DMSO and the volumes were then varied. The compound tested with certained volume was then placed to liquid NA media, homogenized with vortex and then pour to petri disc, left them until solidified. The bacteria suspensions of $P$. aeruginosa and $B$. subtilis were then innoculated on the media at temperature of $37^{\circ} \mathrm{C}$ for $2-3$ days. The growth of bacteria was then monitored every day. The most effective compounds tested were a compound which was the compound with the smallest concentration but the inhibition zone was the biggest ${ }^{26}$.

\section{RESULTS AND DISCUSSION}

The syntheses of diphenyltin(IV) di 3-chlorobenzoate (2) and triphenyltin(IV) 3-chlorobenzoate (4) were performed by reacting diphenyltin (IV) dihydroxide (1) and triphenyltin(IV) hydroxide(3) with 3-chlorobenzoic acid using the a similar procedure reported previously ${ }^{9,14,15,21,22}$.

Some important vibration of IR spectra for the synthesized compound are presented in Table 1. From Table 1, compound 1 has characteristic stretch for $\mathrm{Sn}-\mathrm{O}$ bond at $693.56 \mathrm{~cm}^{-1}$. When 1 was converted to 2 , the new stretch at $1155.86 \mathrm{~cm}^{-1}$ appeared, this peak is characteristic that $\mathrm{Sn}-\mathrm{O}-\mathrm{C}$ has been formed which indicated that bond formation between $\mathrm{Sn}$ and carboxyl group from the acid has been formed.

Table 1: Some selected and important IR band of the compounds ssynthesized

\begin{tabular}{lccccc}
\hline Compound & $\mathbf{1}$ & $\mathbf{2}$ & $\mathbf{3}$ & $\mathbf{4}$ & References \\
\hline Sn-O & 693.56 & 652.68 & - & - & $800-600$ \\
Sn-O-C & - & 1155.86 & - & 1158.10 & $1250-1000$ \\
Sn-ph & 1077.85 & 1072.90 & 1076.83 & 1072.90 & $1100-1000$ \\
OH & 3445.83 & 3447.12 & 3615.51 & 3438.79 & $3100-3500$ \\
C=O & - & 1697.63 & - & 1629.72 & $1760-1600$ \\
C=C & 1470.87 & 1591.60 & 1479.29 & 1551.81 & $1650-1566$ \\
\hline
\end{tabular}

Table2: Microanalytical data of the compounds synthesized

\begin{tabular}{lccc} 
Compounds & \multicolumn{2}{c}{ Elemental Analysis found (Calculated) } \\
& C & H \\
\hline$\left[\left(\mathrm{C}_{6} \mathrm{H}_{5}\right)_{2} \mathrm{Sn}\left(m-\mathrm{C}_{6} \mathrm{H}_{4}(\mathrm{Cl}) \mathrm{COO}\right)_{2}\right](2)$ & $52.35(53.42)$ & $3.05(3.08)$ \\
{$\left[\left(\mathrm{C}_{6} \mathrm{H}_{5}\right)_{3} \mathrm{Sn}\left(m-\mathrm{C}_{6} \mathrm{H}_{4}(\mathrm{Cl}) \mathrm{COO}\right)\right](4)$} & $58.00(59.40)$ & $3.69(3.76)$ \\
\hline
\end{tabular}


Table 3. The $\lambda_{\text {max }}$ of the UV spectra of the organotin(IV) compounds

\begin{tabular}{lcc}
\hline Compound & $\begin{array}{c}\lambda_{\max }(\mathrm{nm}) \\
\pi \rightarrow \pi^{*}\end{array}$ & $\mathrm{n} \rightarrow \pi^{*}$ \\
\hline$\left[\left(\mathrm{C}_{6} \mathrm{H}_{5}\right)_{2} \mathrm{Sn}(\mathrm{OH})_{2}\right](1)$ & 207.00 & 263.00 \\
{$\left[\left(\mathrm{C}_{6} \mathrm{H}_{5}\right)_{2} \mathrm{Sn}\left(m-\mathrm{C}_{6} \mathrm{H}_{4}\right.\right.$} & 235.00 & 272.00 \\
$\left.(\mathrm{Cl}) \mathrm{COO})_{2}\right](2)$ & & \\
{$\left[\left(\mathrm{C}_{6} \mathrm{H}_{5}\right)_{3} \mathrm{Sn}(\mathrm{OH})\right](3)$} & 204.00 & 293.00 \\
{$\left[\left(\mathrm{C}_{6} \mathrm{H}_{5}\right)_{3} \mathrm{Sn}\left(m-\mathrm{C}_{6} \mathrm{H}_{4}\right.\right.$} & 236.00 & 285.00 \\
$(\mathrm{Cl}) \mathrm{COO})](4)$ & & \\
\hline
\end{tabular}

The other characteristic vibration is at $1697.63 \mathrm{~cm}^{-1}$, specific for $\mathrm{C}=\mathrm{O}$ stretch, indicated that carbonyl is present in the compounds.

Table 2 presents the data of microanalysis for the organotin (IV) compounds synthesized. The values obtained generally are very good and compared to the calculated theoretical values were less than $1 \%$.

The $\lambda_{\text {max }}$ of all compounds were obtained by UV spectroscopy analyses. The data obtained are shown in Table 3. Although the shift was not very high, but It is clear that there was some important shifting change in the $\lambda_{\text {max }}$ for each compound. In the spectra, all compounds produced 2 peaks due to transition of $\pi \rightarrow \pi$ and $n \rightarrow \pi *$. For example in compounds 1 , the $\lambda_{\max }$ observed were 207 and $263 \mathrm{~nm}$. In 3 and 4 , there were large shift in the $\pi \rightarrow \pi *$ transition, due to the bound of chlorobenzoate to $\mathrm{Sn}$ atom. The batochromic shift from the starting material to the synthesized compounds were de to the substitution of oxygen in 1 and 3 which was replaced by oxygen atom in chlorobenzoate ${ }^{9,14,115,20,21}$.

The data of ${ }^{1} \mathrm{H}$ and ${ }^{13} \mathrm{C}$ chemical shifts of the organotin (IV) compounds prepared are tabulated in Table 4. The characteristic chemical shift in the spectra of the compounds prepared (Fig. 1) obtained were characterized carefully and compared to some previous results ${ }^{9,14,115,20,21}$. Based on the ${ }^{1} \mathrm{H}$ NMR obtained for compound 2 and 4 , the chemical shifts of phenyl protons attached to tin metal as expected appeared in the range of $7.4-7.6 \mathrm{ppm}$, while the protons in the benzoate ring were at 7.7-7.9 ppm. The chemical shifts of carbon for both compounds also close to the reported values ${ }^{9,14,115,20,21}$. The carbon in the carboxyl group as predicted appeared in the region of 165-166 ppm, while carbon of the phenyl ligand appeared in $\delta$ of 128-130 ppm. The carbons in the chlorobenzoate as expected appeared in $\delta$ range of $130-135 \mathrm{ppm}$ close to the reported values of similar compounds $\mathrm{s}^{9,14,115,20,21}$.

The results of antibacterial by diffusion method are shown Table 5 . The increase of halozone diameter was observed with the increase of concentration of all compounds tested. The triphenyltin (IV) 3-chlorobenzoate was more active in inhibiting $B$. subtilis than $P$. Aeruginosa, as the

Table 4:1 $\mathrm{H}$ and ${ }^{13} \mathrm{C}$ spectra of the organotin(IV) compounds

\begin{tabular}{|c|c|c|c|}
\hline Compound & $\begin{array}{l}\text { H in phenyl } \\
\text { (ppm) }\end{array}$ & $\begin{array}{c}\text { H in benzoate } \\
\text { (ppm) }\end{array}$ & $\begin{array}{c}\text { C in phenyl } \\
\text { and benzoate (ppm) }\end{array}$ \\
\hline $\begin{array}{l}{\left[\left(\mathrm{C}_{6} \mathrm{H}_{5}\right)_{2} \mathrm{Sn}(m-\right.} \\
\left.\left.\mathrm{C}_{6} \mathrm{H}_{4}(\mathrm{Cl}) \mathrm{COO}\right)_{2}\right]\end{array}$ & $\begin{array}{c}\mathrm{H} 2 \& \text { H6 } 7.538 \\
(\mathrm{~d}, 4 \mathrm{H}) ; \mathrm{H} 3 \text { \&H5 } \\
7.554(\mathrm{t}, 4 \mathrm{H}) ; \mathrm{H} 4 \\
7.570(\mathrm{t}, 2 \mathrm{H})\end{array}$ & 7.703-7.991 (m) & $\begin{array}{c}\text { C1-6 (phenyl): 129,3- } \\
\text { 128,8; C7 166,9; C8 } \\
\text { 131,6; C9 130,3; C10 } \\
\text { 134,2; C11 1340; C12 } \\
\text { 130,0; C13 128,4 }\end{array}$ \\
\hline $\begin{array}{l}{\left[\left(\mathrm{C}_{6} \mathrm{H}_{5}\right)_{3} \mathrm{Sn}(m-\right.} \\
\left.\left.\mathrm{C}_{6} \mathrm{H}_{4}(\mathrm{Cl}) \mathrm{COO}\right)\right]\end{array}$ & $\begin{array}{c}\text { H2\&H6 } 7.46 \\
\text { (d,6H); 3\&H5 } 7.43 \\
\text { (t 6); H4 } 7.41\end{array}$ & $7.84-7.85(d)$ & $\begin{array}{c}\text { C1-6 (phenyl): } 129.3 \text { - } \\
\text { 128.8 } \\
\text { 128.8; C7: 165; C8: } \\
\text { 131.6; C9: 130.3; C10: } \\
\text { 134.2; C11: 134.0; } \\
\text { C12: 130.0; C13: 128.4 }\end{array}$ \\
\hline
\end{tabular}


<smiles>Cc1cccc(C(=O)O[As](OS(=O)(=O)c2ccccc2)(c2ccccc2)c2ccccc2)c1</smiles>

(a)<smiles>O=C(O[As](c1ccccc1)(c1ccccc1)c1ccccc1)c1cccc(Cl)c1</smiles>

(b)

Fig. 1: Structure of (a) diphenyltin(IV) di3-chlorobenzoate, (b) triphenytin(IV) 3chlorobenzoate.

inhibition zone observed was bigger in B. subtilis, although it was still smaller than the inhibition zone of the positive control used, chloramphenicol. The differnces in inhibition zone of both bacteria is because $B$. subtilis has higher sensitivty compared to $P$. Aeruginosa perhaps due to the differences of cell wall structure of the bacteria ${ }^{25-27}$.

Based on data presented in Table 6, the compound 4 at concentration of $3.956 \times 10^{-4} \mathrm{M}$, was the most effective concentration that inhibit the growth of the both bacteria. The diffusion method has been applied in order to find the smallest concentration that is able to inhibit the growth of bacteria, thus the ratio comparison has been used to determine the effectivity of the two compounds tested, by observing the wide of clear zone per the number of active compound in the media. The result showed that the concentration of 6 at $3.956 \times 10^{-4}$ $\mathrm{M}(200 \mathrm{ppm})$ has the biggest ratio, even when it is compared with the increased of the concentration of the compound tested.

Table 5: The result of diffusion test againts $P$. aeruginosa and $B$. subtilis

\begin{tabular}{|c|c|c|c|c|c|c|c|c|c|c|}
\hline \multirow{3}{*}{$\begin{array}{l}\text { Compound } \\
\text { (ppm) }\end{array}$} & \multicolumn{8}{|c|}{ Inhibition Zone (cm) } & \multirow{2}{*}{\multicolumn{2}{|c|}{500}} \\
\hline & \multicolumn{2}{|c|}{$\begin{array}{c}\overline{200} \\
(\mathrm{ppm})\end{array}$} & \multicolumn{2}{|c|}{$\begin{array}{c}250 \\
(\mathrm{ppm})\end{array}$} & 300 & & \multicolumn{2}{|c|}{400} & & \\
\hline & P.a & B.s & P.a & B.s & P.a & B.s & P.a & B.s & P.a & B.s \\
\hline $\begin{array}{l}\left.\left[\mathrm{C}_{6} \mathrm{H}_{4}(\mathrm{Cl}) \mathrm{COO}\right)\right] \\
{\left[\left(\mathrm{C}_{6} \mathrm{H}_{5}\right)_{2} \mathrm{Sn}(\mathrm{O})\right](1)} \\
{\left[\left(\mathrm{C}_{6} \mathrm{H}_{5}\right)_{2} \mathrm{Sn}\left(m-\mathrm{C}_{6} \mathrm{H}_{4}(\mathrm{Cl}) \mathrm{COO}\right)_{2}\right](2)} \\
{\left[\left(\mathrm{C}_{6} \mathrm{H}_{5}\right)_{3} \mathrm{Sn}(\mathrm{OH})\right](\mathbf{3})} \\
{\left[\left(\mathrm{C}_{6} \mathrm{H}_{5}\right)_{3} \mathrm{Sn}\left(m-\mathrm{C}_{6} \mathrm{H}_{4}(\mathrm{Cl}) \mathrm{COO}\right)\right](4)} \\
\text { Chloramphenicol }\end{array}$ & $\begin{array}{l}- \\
- \\
- \\
- \\
0.8 \\
1.5\end{array}$ & $\begin{array}{l}- \\
0.8 \\
- \\
0.8 \\
1.0 \\
2.5\end{array}$ & $\begin{array}{l}- \\
- \\
- \\
- \\
0.7 \\
1.5\end{array}$ & $\begin{array}{c}- \\
0.9 \\
- \\
0.9 \\
1.1 \\
2.5\end{array}$ & $\begin{array}{c}- \\
- \\
0.8 \\
- \\
0.8 \\
1.5\end{array}$ & $\begin{array}{c}- \\
0.9 \\
- \\
1.0 \\
1.2 \\
2.5\end{array}$ & $\begin{array}{c}- \\
- \\
0.8 \\
- \\
0.9 \\
1.5\end{array}$ & $\begin{array}{l}- \\
1.0 \\
- \\
1.1 \\
1.3 \\
2.5\end{array}$ & $\begin{array}{l}- \\
- \\
- \\
- \\
0.9 \\
1.5\end{array}$ & $\begin{array}{l}1.0 \\
- \\
1.1 \\
1.4 \\
2.5\end{array}$ \\
\hline $\begin{array}{l}\text { P.a. = Pseudomonas aeruginosa } \\
\text { Positive control = Chloramphenic }\end{array}$ & & 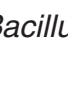 & tilis, & & & & & & & \\
\hline
\end{tabular}

Table 6: The inhibition percentage of ccompound tested against $P$. aeruginosa and $B$. subtilis

\begin{tabular}{|c|c|c|c|c|c|c|c|c|c|c|}
\hline \multirow[t]{3}{*}{ Compound } & \multicolumn{10}{|c|}{$\%$ Inhibition } \\
\hline & \multicolumn{2}{|c|}{$\begin{array}{l}200 \\
(p p m)\end{array}$} & \multicolumn{2}{|c|}{$\begin{array}{l}250 \\
\text { (ppm) }\end{array}$} & \multicolumn{2}{|c|}{$\begin{array}{l}300 \\
(\mathrm{ppm})\end{array}$} & \multicolumn{2}{|c|}{$\begin{array}{l}400 \\
\text { (ppm) }\end{array}$} & \multicolumn{2}{|c|}{$\begin{array}{l}500 \\
\text { (ppm) }\end{array}$} \\
\hline & P.a & B.s & P.a & B.s & P.a & B.s & P.a & B.s & P.a & B.s \\
\hline $\begin{array}{l}{\left[\left(\mathrm{C}_{6} \mathrm{H}_{5}\right)_{2} \mathrm{Sn}\left(m-\mathrm{C}_{6} \mathrm{H}_{4}\right.\right.} \\
\left.(\mathrm{Cl}) \mathrm{COO})_{2}\right](2)\end{array}$ & - & - & - & - & 0.003 & - & 0.003 & - & - & - \\
\hline $\begin{array}{l}{\left[\left(\mathrm{C}_{6} \mathrm{H}_{5}\right)_{3} \mathrm{Sn}\left(m-\mathrm{C}_{6} \mathrm{H}_{4}\right.\right.} \\
(\mathrm{Cl}) \mathrm{COO})](4)\end{array}$ & 0.004 & 0.005 & 0.003 & 0.004 & 0.003 & 0.004 & 0.002 & 0.003 & 0.002 & 0.003 \\
\hline
\end{tabular}

P.a. = Pseudomonas aeruginosa, B.s. = Bacillus subtilis,

Positive control $=$ Chloramphenicol 
Table 7: The result of dilution test of comppound 4 against $P$. aeruginosa and $B$. subtilis

\begin{tabular}{llllll}
\hline Bacteria & \multicolumn{5}{c}{ Volume of $\mathbf{4}(\mathbf{m L})$} \\
\hline & 0.5 & 1 & 1.5 & 2 & 2.5 \\
P. aeruginosaB. subtilis & +++++++++ & ++++++++ & ++++++ & ++++ & - \\
\hline
\end{tabular}

Note of Bacterial growth:

\begin{tabular}{|c|c|}
\hline +++++ & $=$ very high \\
\hline ++++ & $=$ high \\
\hline +++ & $=$ medium \\
\hline++ & $=$ little \\
\hline+ & $=$ very little \\
\hline- & $=$ no grwoth \\
\hline
\end{tabular}

The result of dilution test is shown in Table 7. The compound 4 in concentration 3.956 $\times 10^{-4} \mathrm{M}(200 \mathrm{ppm})$ with volume used $2.5 \mathrm{~mL}$ per media was able to inhibit maximally the growth of both bacteria, while at other volumes, the bacteria were still able to grow.

The microorganism inhibition mechanism by antibacterial substances may be caused by some factors, such as the disturbance in the compound composition of cell wall, the increase of cell membrane permeability which cause the loss of component cell structure, the inactivation of enzyme and destruction or damaging the function of genetic materials ${ }^{25}$.

In this biologial activity test, the compound 4 where its compound is more electropositive than 3 , disturb the electronegative bacteria cell wall, thus the interaction cause the disruption of bacteria growth.

\section{CONCLUSION}

The derivatives of organotin(IV) compound, diphenyltin(IV) di-3-chlorobenzoate and
triphenyltin(IV) 3-chlorobenzoate were prepared. Based on the result obtained, they have shown to be potentially used as antibacterial substances. The triphenyltin(IV) derivative has been shown to be more active than diphenyltin(IV) derivative. This finding was in line with other data relating to the number of carbon atom present in the compound and might also relate to the ability of phenyl ligand to draw electron from the metal center as a result the metal became more positive and reacted actively with electronegative cell of bacteria, thus the growth of bacteria was disrupted. However, we aim to have a better antibacterial substance which has much smaller inhibition concentration.

\section{ACKNOWLEDGMENT}

Annisa would like to thank to the Head of Sekolah Tinggi Ilmu Kesehatan Faletehan SerangBanten for financial support for her study especially for the final research. Thanks also go to Prof. Bohari M. Yamin, Universiti Kebangsaan Malaysia for helping in doing microanalysis and Prof. Dr. Hasnah Osman of School of Chemistry, University of Sains Malaysia for NMR experimentation.

\section{REFERENCES}

1. Jawetz, E. and M. Adelberg. Mikrobiologi Kedokteran Edisi Ke-3.Alih Bahasa : Huriwati Hartanto dkk. Penerbit Buku Kedokteran ECG.Jakarta. 2005.

2. Nursal, S. Wulandari, W.S. Juwita. Bioaktifitas Ekstrak Jahe (Zingiber officinale Roxb.) dalam
Menghambat Pertumbuhan Koloni Bakteri Escherichia coli dan Bacillus subtilis. J. Biogen. 2006, 2, 64-66. (in Indonesian)

3. Irianto, K.. Mikrobiologi Menguak Dunia Mikroorganisme Jilid 2. Bandung: CV. Yrama Widya. 2007 (In Indonesian) 
4. Pelczar,M.J, Chan, E.C.S.Dasardasarmikrobiologi2.Diterjemahkan oleh Hadioetomo RS, Imas T, Tjitrosomo SS, Angka SL. PenerbitUniversitas Indonesia. Jakarta. 1986; pp.489-522

5. Kang, W., Wu, X., Huang, J. J. Organo.Chem. 2009, 694, 2402-2408.

6. Win, Y.F., Teoh,S.G., Lim, E.K., Ng,S.L., Fun, H.K. J. Chem. Crystal. 2008, 38, 345-350.

7. Alama, A., Tasso, B., Novelli, F., Sparatore, F., Drug Discov. Today 2009, 14, 500-508.

8. Affan, M.A., Foo,S.W., Jusoh,I., Hanapi, S., Tiekink, E.R.T. Inor. Chem. Acta 2009,362, 5031-5037.

9. Hadi, S.; Irawan, B.; Efri. J. Appl. Sci. Res. 2008, 4, 1521-1525.

10. Manav, N., Ghandhi, N., Kaushik,N.K. J. Therm. Anal. Calorom. 2000,61: 127-134.

11. Singh, R., Kaushik, N.K. Spec. Acta Part A: Mol. Biomol. Spectr.2008,71, 669-675.

12. Mohan, M., Agarwal, A., Jha, N.K. J. Inor. Biochem. 1988,34, 41-54.

13. Gielen, M. J. Braz. Chem. Soc. 2003, 14, 870877.

14. Hadi, S.; Rilyanti, M.; Suharso. Indo. J. Chem. 2012, 12, 172-177.

15. Hadi, S.; Rilyanti, M. Orient. J. Chem. 2010,26, 775-779.

16. Singh, N.K., Srivastava, A., Sodhi, A., Ranjan, P. Transit. Metal Chem. 2000, 25, 133-140.

17. Maiti, A., Guha, A.K., Ghosh, S. J. Inor. Biochem. 1988,33, 57-65.
18. Win Y. F., Teoh, S. G., Vikneswaran, M. R., Sivasothy,Y., Ha,S. T., Ibrahim, P. Aus. J. Basic Appl. Sci. 2010,4,: 5923-5931

19. Pellerito, L.; Nagy, L., Coord. Chem. Rev. 2002, 224, 111-150.

20. Kurniasiah, $\mathrm{H}$, Nurissalam, $\mathrm{M}$, Iswantoro, B , Afriyani,H , Qudus,H.I., Hadi., S., Orient. J. Chem. 2015, 31, 2377-2383.

21. Hadi, S., Rilyanti, M.; Nurhasanah. ModernAppl. Sci. 2009, 3, 12-17.

22. Rastogi, R.B.; Singh, M.M.; Singh, K.; Yadav,M. Port. Electrochim. Acta. 2005, 22, 315-332.

23. Singh, R.; Chaudary, P.; Khausik, N.K. Rev. Inorg. Chem. 2010, 30, 275-294.

24. Szorcsik, A.; Nagy, L.; Gadja-Schrantz, K.;Pellerito, L.; Nagy, E.; Edelmann, E.T. J.Radioanal. Nucl. Chem. 2002, 252, 523530.

25. Jawetz, E., Melnick, L.J.; Adelberg, A.E.. Mikrobiologi untuk Profesi Kesehatan ed 16, terjemahan Tonang, H.egc Penerbit Buku Kedokteran. Jakarta. 1986; Hal.31,34,145147,150-152.

26. Lorian, V. Antibiotics in Laboratory Medical. Wiliam and Wilkins Co.Baltimore. London. 1980; Hal. 1-22, 170-178, 511-512.

27. Ibrahim, M. Mikrobiologi: Prinsip dan Aplikasi. Surabaya: Unesa University Press. 2007. (In Indonesian) 